\title{
Analisis Kenyamanan Desain Interior di Supermarket Studi Kasus : Ranch Market dan The Gourmet Nancy Halim ${ }^{1}$, Grace Kattu ${ }^{2}$
}

Program Studi Seni dan Desain, Universitas Kristen Petra, Surabaya, Jawa Timur, Indonesia. Email: m41416142@john.petra.ac.id, gracesika@ petra.ac.id

\begin{abstract}
Abstrak
Dalam desain interior, kenyamanan sama pentingnya dengan keindahan desain. Tanpa kenyamanan, pengguna hanya dapat menikmati desain sejauh mata berjalan tetapi tidak dapat digunakan oleh pengguna karenanya nilai desain terdegradasi karena desain interior tergantung pada kenyamanan, kualitas, dan estetika. Tanpa kenyamanan dalam desain interior, estetikanya tidak bisa dinikmati. Dengan demikian, kenyamanan dalam desain interior harus hadir pada elemen kunci di interior agar desain dapat ditangkap oleh orang yang melihatnya. Angka yang paling tinggi pada pengguna adalah interior ritel. Desain toko ritel telah mengambil dunia interior dengan sungguh-sungguh, karena ritel selain dari produk yang dijualnya, desain interior sangat mengambil kesuksesan toko ritel. Seiring dengan meningkatnya kebutuhan, toko-toko telah naik untuk memberikan tuntutan tinggi dalam kebutuhan sehari-hari. Sebagian besar kebutuhan seharihari adalah produk makanan, kebersihan, dan kebutuhan lainnya yang banyak ditemukan di Supermarket yang berada di banyak lokasi pedesaan di Surabaya. Di Surabaya saja, toko ritel adalah jantung dan jiwa terhadap kesehatan keuangan dan interaksi sosialnya di masyarakat lebih lanjut, Supermarket telah tumbuh dalam desain interiornya juga merupakan barang dagangan visual yang dikandungnya. Pada akun itu, penelitian ini berfokus pada analisis lebih lanjut ke dalam kenyamanan yang sesuai dalam desain interior yang menunjukkan apakah objek yang kami teliti, mengambil kenyamanan desain interior karena rencana desain toko. Metode yang digunakan pada penilitian ini adalah metode observasi langsung objek dan analisa. Dalam analisa penilitian, ditemukan bahwa objek yang diteliti masih cukup memenuhi standar kenyamanan interior, meskipun masih ada kekurangan dalam desain yang bisa lebih dikembangkan lagi.
\end{abstract}

Kata kunci: Supermarket, Ritel, Desain Interior, Kenyamanan Ruang

\begin{abstract}
In interior design, comfort is just as important as the beauty of the design. Without comfort, user can only enjoy the design as far as the eyes goes but it is unusable for the user hence the value of the design is degraded as interior design depends on the comfort, quality, and beauty. Without comfort in interior design, the beauty cannot be enjoyed. As such, comfort in interior design must be present on the key elements in the interior for the design to be apprehend by the beholders. The most high numbers in users are retail interior. Retail store designs has taken the interior world earnestly, as retails aside from the products its selling, the interior design takes on highly on the success of a retail store. As needs increases, stores has gone up to provide high demands in daily needs. Most of the daily needs are food products, hygene, and other necessities which are found in Supermarkets that are located in many rural locations in Surabaya. In Surabaya alone, retails store are the heart and soul to its financial health and social interaction in community furthermore, Supermarkets has grown in both its interior design also the visual merchandise it contains. On that account, this research focuses on the analysis further into the approriate comfort within the interior design that indicates whether the object we researched on, takes comfort of interior design into account of the store's design plan. The method used in this study is the method of direct observation of the objects and analysis. In the research analysis, it was found that the objects studied still adequately meet the standards of interior comfort, although there are still shortcomings in the design that can be further developed.
\end{abstract}


Keywords: Supermarket, Retail, Interior Design, Comfortable Space

\section{Pendahuluan}

Kehidupan modern dengan segala kebutuhan yang semakin beragam mengakibatkan semakinbermunculan toko retail seperti supermarket, toko swalayan, mini market, hypermarket dan lain sebagainya. Dengan adanya toko retail kebutuhan manusia sehari-hari dapat terpenuhi dengan cepat dan praktis. Keberadaan supermarket banyak ditemui di setiap area tempat tinggal masyarakat dan hadir dengan berbagai macam konsep yang menyediakan produk-produk bervariasi. Supermarket hadir dengan konsep modern, yang merupakan perkembangan dari toko atau pasar tradisional. Supermarket lebih diminati oleh pembeli karena bertempat di lokasi yang dekat dari residensial populasi, dengan interio yang lebih modern dan di desain secara strategis untuk mendukung kenyamanan pembeli dengan segala kebutuhan dalam berbagai macam kategori produk, baik produk luar maupun lokal dengan kualitas tinggi. Toko ritel supermarket tidak hanya menawarkan pengalaman belanja yang lebih nyaman tetapi juga menyajikan ruang menarik lainnya seperti fasilitas hiburan, tempat makan, dan rekreasi.

Pembeli akan membeli di sebuah supermarket karena beberapa faktor, salah satu faktor yang menentukan adalah karakter fisik dari supermarket. Menurut Shari Water (guide from $w w w . a b o u t$;retail) karateristik fisik dan pengaruh yang mengelilingi sesuatu bisnis retail dapat menimbulkan citra dalam usaha untuk menarik konsumen, seperti perencanaan lighting dan penataan interior yang menarik untuk menciptakan suasana atmostphere store yang pas. Desain toko yang menarik akan membangkitkan niat atau merangsang keinginan untuk berbelanja dalam benak konsumen, Hal ini tidak terlepas dari kenyamanan desain interior yang sangat berperan dalam lighting dan atmosphere store dan juga penataan yang menarik dalam sebuah supermarket. Desain ritel merupakan kombinasi dari karateristik fisik toko seperti arsitektur, tata letak, pencahayan, pemanjangan, warna, temperatur, musik, aroma yang secara menyeluruh akan menciptakan citra dalam benak konsumen.

Maka dari masalah-masalah yang dapat ditemukan di supermarket terutama dalam general interior nya, pada elemen-elemen interior terdiri dari flooring (tata letak toko) penentuan jenis lantai(kayu, keramik,karpet) ukuran, desain dan warna lantai. Color and Lighting. Warna dan pencahayaan dapat menciptakan sebuah image toko. Lighting sangat beperan penting dalam retail karena dapat membuat produk-produk yang ditawarkan lebih menarik dan terlihat berbeda. Fixtures (penempatan) pemilihan pelaratan menunjang harus tepat tidak hanya untuk kegunaan melainkan cara penempatan yang sesuai kebutuhan dan bisa terlihat estetik secara bersamaan. Scent and aroma (aroma dan musik) aroma dan musik ada perannya dalam menciptakan suasana toko yang bisa membuat suasana toko terasa nyaman, santai untuk konsumen yang berasa didalam toko. Temperature (suhu) suhu ruangan juga berpengaruh pada kenyamaan konsumen. Dengan ruang yang sejuk bisa membuat konsumen betah berada didalamnya dan akan menghabiskan waktu yang lebih lama dibandingkan toko dengan ruang yang panas, konsumen akan tidak betah karena ketidaknyamannya suhu toko. Width of ailes (lebar gang) jarak antara rak barang harus diatur sedemikian sehingga konsumen merasa nyaman saat berbelanja. cash register (kasir) penempatan kasir harus strategis agar menghindari kemacetan/antrian. Dan juga penentuan jumlah kasir yang sesuai dan memadai.

Ranch Market adalah sebuah supermarket modern yang popular di Surabaya dikalangan anak muda. Ranch Market didirikan pada tanggal 29 Mei 1997 dengan kegiatan usaha utama bergerak dibidang perdagangan ritel modern. Nama perusahaan belum pernah dirubah sejak pendiriannya hingga saat ini. Kegiatan usaha perusahaan diawali pada tahun 1998 dengan membuka gerai Ranch Market di Jakarta sebagai supermarket pertama, yang merupakan lisensi waralaba dari Ranch Market USA. Pada tahun 2010 perusahaan melakukan pemutusan lisensi dengan Ranch Market USA namun masih memiliki ijin untuk menggunakan merk Ranch Market di Indonesia dan terpisah dengan Ranch market USA. Perusahaan kemudian melakukan pembenahan dan 
mengembangkan Ranch Market untuk disesuaikan dengan pasar dan gaya hidup masyarakat Indonesia. Perusahaan memiliki 4 brand supermarket yaitu Ranch Market, Farmers Market, the Gourmet by Ranch Market dan day2day by Farmers Market. Ranch Market adalah supermarket yang nemawarkan produk-produk berkualitas tinggi dan unik dan ditujukan untuk pangsa pasar kelas atas dan menengah atas. Produk-produk yang berkualitas tinggi dan produk yang sesuai dengan gaya hidup sehat pelanggannya seperti produk organik, gluten free product dan dietary product yang berbeda dengan supermarket lainnya. (sumber: ranchmarket.co.id) Setiap Ranch Market memiliki desain interior menarik dengan elemen-elemen interior dan store atmosphere berbeda.

Berdasarkan observasi awal yang dilakukan di Ranch Market dan The Gourmet galaxy mall terdapat perbedaan desain disetiap supermarket. Perbedaan terdapat pada konsep, lighting dan ambiens yang tercipta dan juga atmosphere store serta sirkulasi didalamnya. Dan dari hal tersebut diatas kenyamanan desain interior tiap supermarket terdapat perbedaan yang menarik untuk diteliti. Ranch Market Galaxy Mall memiliki suasana hangat dengan menggunakan pencahayaan warm tone, dengan pemilihan warna coklat dan warna neutral lainnya membuat store atmosphere tersebut berbeda dengan supermarket lainnya yang menggunakan pencahayaan terang dengan tone dingin. Observasi awal ini mendorong penieliti untuk meneliti lebih dalam tentang kenyamanan desain interior pada toko ritel supermarket Ranch Market Galaxy Mall.

\section{Metode}

Rancangan pada penelitian ini memungkinkan untuk melakukan pendekatan kualitatif, yaitu dengan melakukan pengumpulan data malalui observasi perilaku, dokumentasi, analisis data dan studi kasus. Pengumpulan data lapangan dilokasi dimana para partisipan mengalami isu atau masalah yang akan di teliti. Informasi yang dikumpulkan dengan melihat mereka bertingkah laku dalam konteks natural melakukan interaksi face-to-face. Mengumpulkan data yang spesifik dari objek dan subjek yang ditunjukan, menganalisis data mulai dari tema-tema yang khusus ke tematema umum, dan menafsirkan makna data. Laporan akhir untuk penilitian ini memiliki struktur fleksibel. (Creswell, 2007). Model teori yang digunakan sebagai adalah model teori deduktif atau deduksi adalah model dimana teori masih menjadi alat penelitian sejak memilih dan menemukan masalah, membangun hipotesis maupun melakukan pengamatan di lapangan sampai dengan menguji data. (Bungin). Untuk observasi objek, diambil dari pengalaman-pengalaman pribadi agak memahami pengalaman partisipan yang akan di teliti

Salah satu teknik yang dapat digunakan untuk mengetahui atau menyelidiki tingkah laku nonverbal yakni dengan menggunakan teknik observasi. Metode observasi atau pengamatan adalah kegiatan keseharian manusia dengan menggunakan panca indera mata dan dibantu dengan panca indera lainya. Kunci keberhasilan observasi sebagai teknik pengumpulan data sangat banyak ditentukan pengamat sendiri, sebab pengamat melihat, mendengar, mencium, atau mendengarkan suatu onjek penelitian dan kemudian ia menyimpulkan dari apa yang ia amati itu. Pengamat adalah kunci keberhasilan dan ketepatan hasil penelitian (Yusuf, 2014). Observasi untuk tujuan empiris mempunyai tujuan bermacam-macam. Observasi juga memiliki fungsi bervariasi. Tujuan dari observasi berupa deskripsi, melahirkan teori dan hipotesis (pada penelitian kualitatif), atau menguji teori dan hipotesis (pada penelitian kuantitatif). Fungsi observasi secara lebih rinci terdiri dari deskripsi, mengisi, dan memberikan data yang dapat digeneralisasikan. Deskripsi, berarti observasi digunakan untuk menjelaskan, memberikan, dan merinci gejala yang terjadi, seperti seorang laboran menjelaskan prosedur kerja atom hidrogen, atau ahli komunikasi menjelaskan secara rinci prosedur kerja di stasiun televisi. Mengisi data, memiliki maksud bahwa observasi yang dilakukan berfungsi melengkapi informasi ilmiah atas gejala sosial yang diteliti melalui teknik-teknik penelitian. Memberikan data yang dapat digeneralisasikan, maksudnya adalah setiap kegiatan penelitian, sehingga mengakibatkan respon atau reaksi dari subjek amatan. Dari gejalagejala yang ada, peneliti dapat mengambil kesimpulan umum dari gejala-gejala tersebut (Hasanah, 2017). 
Melakukan observasi deskriptif dengan tahapan metode analisis data yang dilakukan oleh peneliti dalam penelitian ini yaitu:

1. Analisis sebelum di lapangan

Proses analisis sebelum di lapangan dilakukan dengan melakukan analisis data terhadap studi literatur yang telah diketahui dasar tingkat kenyamanan ruang ritel.

2. Analisis data selama di lapangan

Proses analisis data yang dilakukan di lapangan dilakukan dengan melakukan observasi objek. Observasi adalah bagian dalam pengumpulan data. Dengan Observasi berarti mengumpulkan data langsung dari lapangan (Semiawan, 2010). Subjek dilapangan dan juga membuat catatan lapangan dari hasil analisis data yang ditemukan yang memuat tentang apa yang sudah diamati, didengar dan dipikirkan peniliti yang sesuai dengan data teori yang sudah dikemukakan.

\section{Pembahasan}

Berdasarkan analisa deskripsi yang telah dilakukan, definisi dari kenyamanan Desain Interior pada Supermarket adalah dimana interior pada Supermarket memenuhi kebutuhan dasar manusia, yang memenuhi kriteria kenyamanan dengan adanya aksesibilitas, kemudahan berkomunikasi (internal/eksternal, langsung atau tidak langsung), kemudahan berkegiatan (prasarana dan sarana lingkungan tersedia). Sehingga dapat disimpulkan jika kenyamanan adalah kondisi saat terpenuhinya kebutuhan dasar sehingga tercipta perasaan nyaman. Supermarket yang menyediakan berbagai kebutuhan dasar manusia dari makanan, minuman dan lainnya, bukan hanya menyediakan berbagai macam barang jualan kebutuhan tetapi juga memenuhi kenyamanan pada Interior saat beraktivitas dan menghabiskan waktu didalam sebuah supermarket. Dari observasi yang telah dilaksanakan, diperoleh data tentang akustik, pencahayaan, penghawaan, pewarnaan ruang, sirkulasi ruang Supermarket yang digunakan yaitu Ranch Market dan The Gourmet by Ranch Market.

\section{Ranch Market}

\section{A. Tampak Depan Toko (Fasade)}

Tampak depan Ranch Market memiliki tiga area, yaitu entrance, window shop, dan area checkout (pintu keluar). Fasade area entrance komunikatif dengan mempunyai Marquee (nama toko dan logo) pada depan entrance toko sehingga menampilkan kesan unik menjadi Trademark pada Ranch Market. Area window shop, terdapat kaca bening yang menampilkan tampak supermarket, namun layaknya seperti kegunaan window shop pada biasanya, window shop pada Ranch Market ini tidak sepenuhnya di gunakan dengan baik sebagai area show produk. Area checkout memiliki area yang terbuka dengan menggunakan pintu gerbang yang bisa di cabut-pasang sesuai jam buka dan tutup toko. 


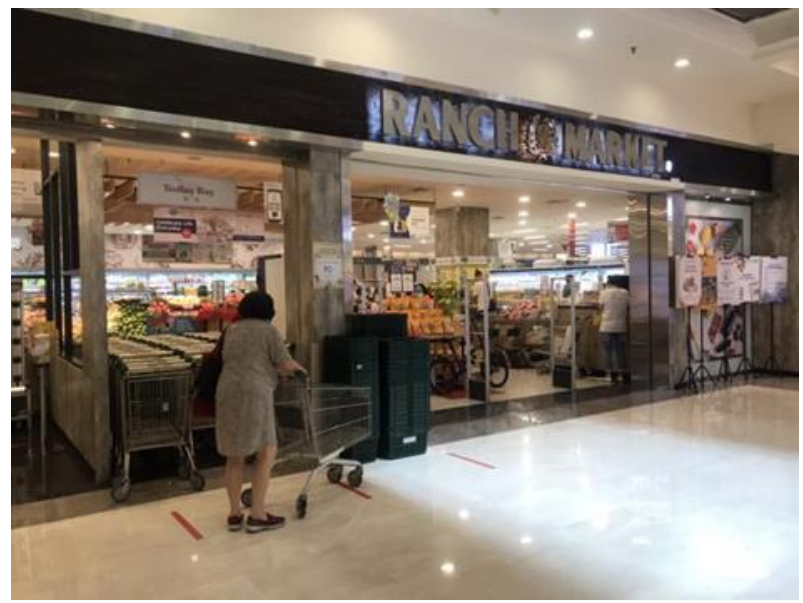

Gambar 1. Tampak Depan Ranch Market Galaxy Mall Sumber : Dokumentasi Pribadi

\section{B. Tata Letak (Denah Layout)}

Tata ruang pada Ranch Market memiliki denah yang memanjang ke samping dengan tata letak sederhana dengan kombinasi tata letak horizontal dan vertikal yang diatur berdasarkan kategori produk. Tata ruangnya cukup effisien dengan bisa memuat banyak fixtures. Area depan entrance terdapat island display. Area gang island display kurang ruang yang cukup sehingga terasa sempit, namun masih bisa di akses oleh pengunjung. Area tengah-belakang adalah area dimana terdapat display produk dengan shelving display, di antar gang area ini cukup luas untuk dilewati beberapa pengunjung sekaligus. Pada Area checkout kurang luas dan cukup sempit untuk di lewati beberapa pengunjung sekaligus terutama pada saat ada antrian untuk checkout.

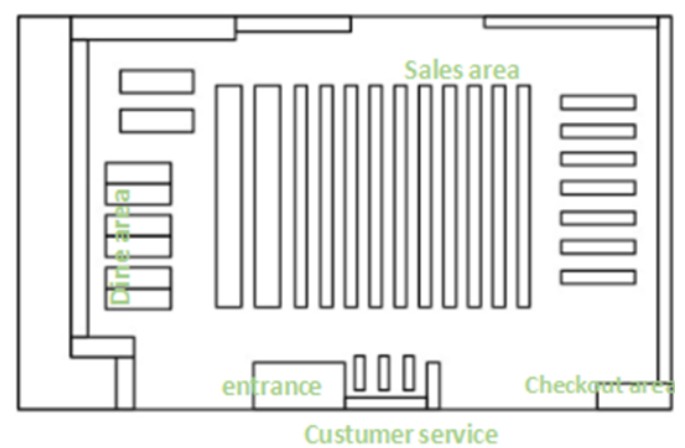

Gambar 2. Layout Ranch Market

Sumber: Dokumentasi Pribadi

C. Akustik Ruang

Dari hasil observasi peneliti, Ranch Market mempunyai suasana ruang yang tergantung pada pengunjung yang ada, dan terdapat suara dari ruang luar supermarket. Tetapi selama berada didalam supermarket, suara dari luar dan dari pengunjung yang datang tidak mengganggu aktivitas pengguna.

D. Pencahayaan Ruang 
Dari hasil observasi peneliti, supermarket mempunyai pencahayaan yang sangat memadai. Untuk siang terdapat sinar matahari dari jendela di bagian pojok supermarket dan menggunakan pencahayaan buatan dikarenakan kurangnya cahaya dari jendela untuk memadai pencahayaan seluruh ruangan sehingga pencahayahaan buatan menjadi pencahayaan utama dari supermarket. Pencahayaan pada Ranch Market, rata-rata tingkat pencahayaan adalah 1200lux. Standar pencahayaan yang direkomendasikan untuk ruang ritel adalah rata-rata di kisaran Tampilan aksen terang ditambah dengan dinding perimeter dan display (1076-3229 lux) untuk membantu menghidupkan karakter dari sebuah ruang ritel. sehingga dapat disimpulkan pencahayaan Supermarket Ranch Market cukup memenuhi syarat kenyamanan ruang, dikarenakan data pencahayaan yang telah didapatkan antara angka standar pencahayaan.

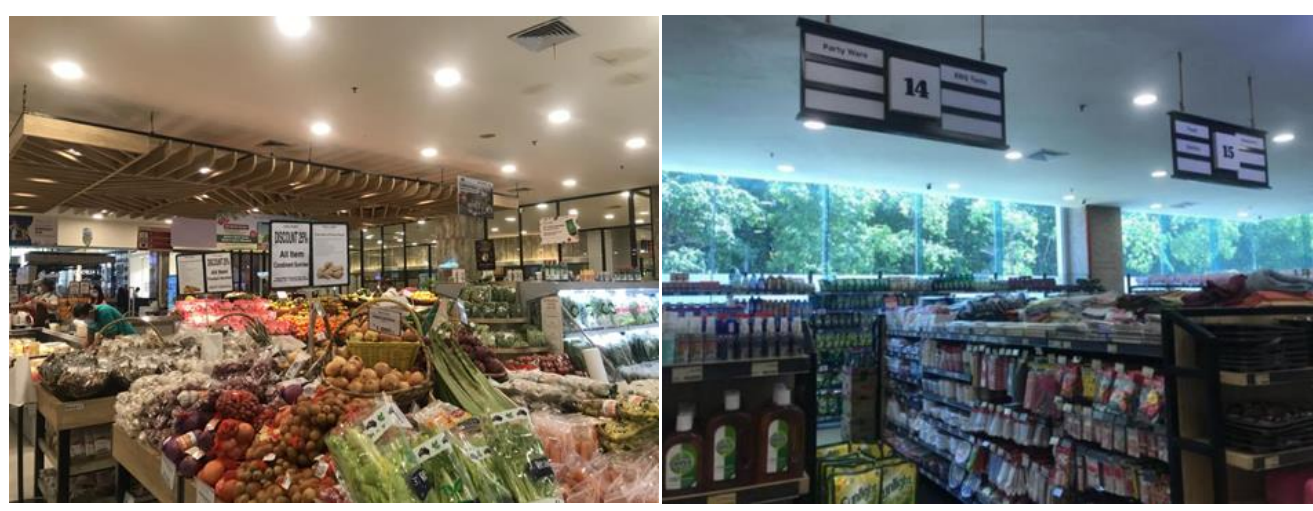

Gambar 3. Pencahayaan Alami dan Buatan Ranch Market Sumber : Dokumentasi Pribadi

E. Penghawaan Ruang

Dari hasil observasi, Supermarket sudah mempunyai penghawaan yang cukup. Penghawaan dalam Supermarket menggunakan penghawaan buatan AC central. Berikut adalah gambar ruangan dengan penghawaannya yang memadai. Penghawaan pada Ranch Market, rata-rata suhu saat siang dalam ruangan adalah sekitar $25 \mathrm{C}$. Sedangkan saat malam adalah sekitar $22 \mathrm{oC}$. Kemudian untuk rata-rata suhu saat siang di luar ruangan adalah sekitar $25 \mathrm{C}$. Sedangkan saat malam adalah sekitar 22C. Sedangkan standar penghawaan yang direkomendasikan adalah sekitar 20,5C-31,0C. Dengan demikian, dapat disimpulkan bahwa penghawaan pada Ranch Market, cukup memenuhi syarat kenyamanan ruang, dikarenakan data penghawaan memenuhi syarat kenyamanan ruang karena masuk dalam lingkup standar penghawaan yang telah ditetapkan.

\section{F. Sirkulasi dan Aksesibilitas Ruang}

Dari hasil observasi, Ranch Market mempunyai pola sirkulasi Linier yang mempunyai jalan lurus, memotong jalan lain, dan bercabang-cabang, Pola ini mendukung layout Supermarket yang notabene memanjang. Untuk sirkulasinya terasa agak sempit pada jarak beberapa stand produk sayur. Tetapi untuk sirkulasi minimal satu orang jalan, sudah cukup memadai. Untuk sebagian besar area seperti island display dan ailes sudah memenuhi jarak minimum untuk trolly dan pengunjung. Berikut adalah gambar sirkulasi kafe beserta datanya. Sirkulasi pada Ranch market dari 5 kasus sirkulasi utama yang telah dianalisa datanya, terdapat 3 kasus yang memenuhi standar minimal untuk sirkulasi orang berlalu-lalang, yaitu $76.2 \mathrm{~cm}$ untuk area island display, $91.4 \mathrm{~cm}$ untuk area shelving dan checkout. Dengan demikian, dapat disimpulkan bahwa Ranch Market, cukup memenuhi syarat kenyamanan ruang, dikarenakan 
data sirkulasi ruang memenuhi syarat kenyamanan ruang karena masuk dalam lingkup standar sirkulasi yang telah ditetapkan.

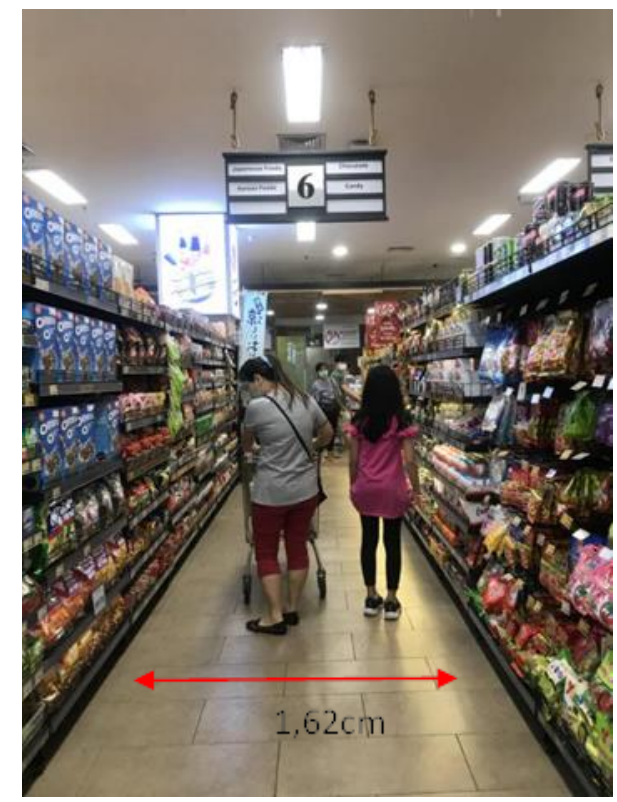

Gambar 4. Aksesibilitas Area Display

Sumber: Dokumen Pribadi

G. Signage dan graphics

Dari hasil observasi, Supermarket Ranch Market mempunyai tanda wayfinding untuk produk cukup jelas. Dengan menggunakan signage melayang pada seluruh toko, ini membuat pengunjung mencari suatu produk tertentu lebih mudah. Ukuran font yang cukup, dengan penggunaan font yang jelas dan padat. Penggunaan warna yang bisa jelas dilihat. Tipografi dan warna pada tanda konsisten diseluruh toko. displaying merchandise di supermarket Ranch Market ini, sudah cukup menarik dari tema, desain dan warna. Exterior sampai pada interior supermarket, Desain dan warna pada fixture, shelves dan signage yang konsisten dengan gaya dan tema pada supermarket Ranch Market.

\section{The Gourmet by Ranch Market}

A. Tampak Depan (Fasade)

The gourmet by Ranch Market adalah supermarket yang bergaya interior modern industrial yang mempunyai gaya interior yang berbeda dari Ranch Market. Gaya yang dimiliki oleh the gourmet adalah modern industrial yang memiliki karakter minimalis dengan warna hitam, dan untuk marquee toko menggunakan nama dan logo lampu yang kontras dari warna background. Seperti Ranch Market, Denah layout Ranch memiliki kesamaan denah dengan satu pintu masuk dan satu pintu checkout dengan fasade memanjang kesamping. 


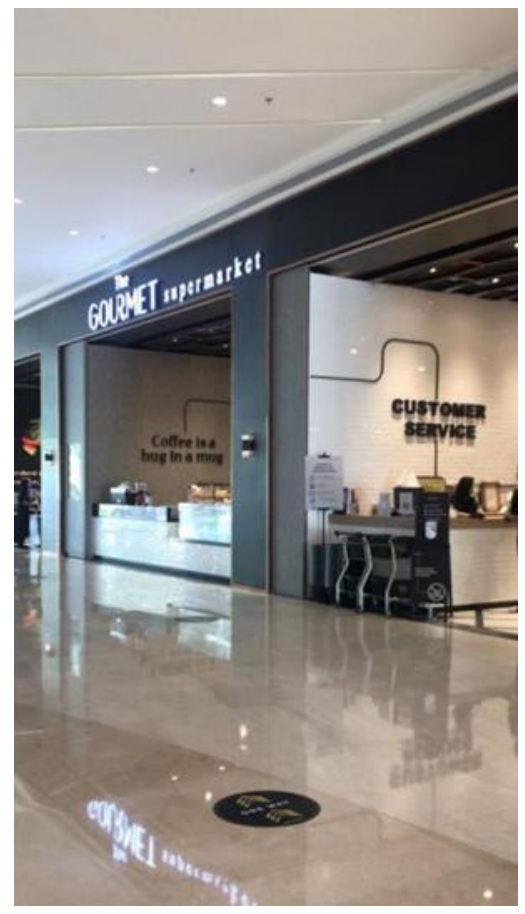

Gambar 5. Tampak Depan The Gourmet by Ranch Market Sumber : Dokumen Pribadi

B. Tata Letak (Layout)

Seperti Ranch Market, Denah layout The Gourmet memiliki kesamaan denah dengan satu pintu masuk dan satu pintu checkout dengan fasade lebar kesamping, dan memanjang kebelakang. Tata letak dari The Gourmet memiliki tata letak yang vertikal diseluruh toko. Tata letak entrance cukup luas dan nyaman untuk dilewati, area sales memiliki ruang yang cukup untuk dilewati satu orang pengunjung. Area checkout cukup luas dan untuk bebrapa pengunjung. 


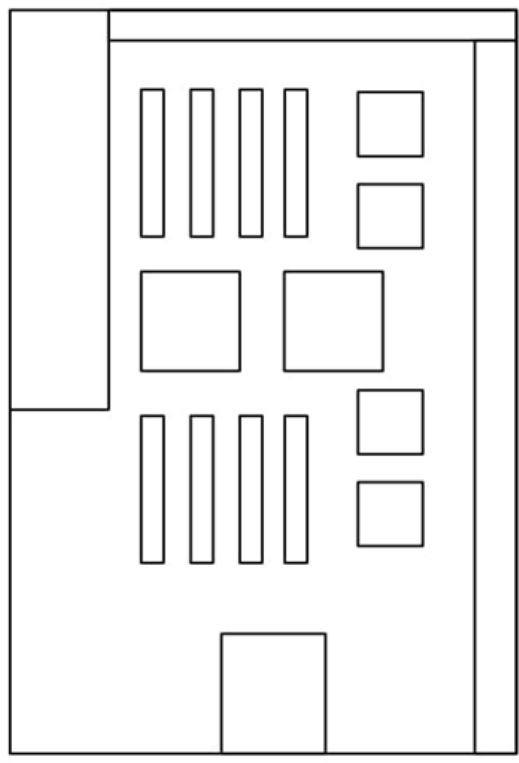

Gambar 6. Layout The Gourmet Sumber : Dukumen Pribadi

\section{Akustik Ruang}

Dari hasil observasi peneliti, The Gourmet mempunyai suasana ruang yang nyaman, tenang, tidak berisik, juga adanya musik dengan pilihan lagu yang cocok membuat ruangan ini nyaman untuk menghabiskan waktu dalam berbelanja.

\section{Pencahayaan Ruang}

Dari hasil observasi peneliti, supermarket mempunyai pencahayaan yang sangat memadai. Supermarket ini menggunakan pencahayaan buatan pada seluruh ruangan, meskipun masih mendapat pencahayaan alami dari sinar matahari di siang hari yang terdapat dari bukaan jendela dan pintu kaca di sisi kiri toko Berikut adalah gambar ruangan dengan pencahayaannya yang memadai.

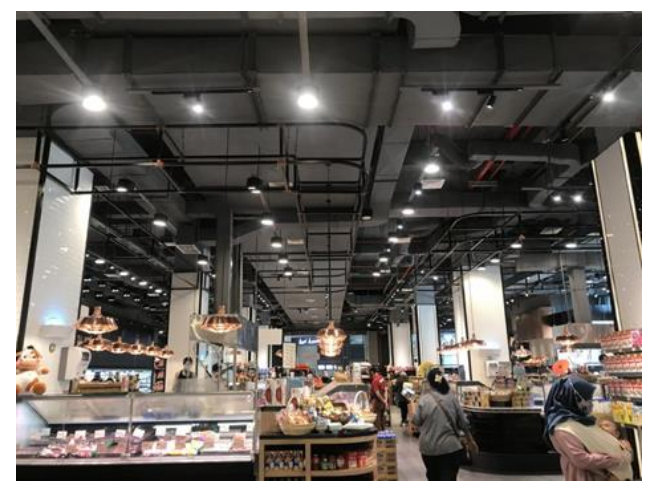

Gambar 7. Pencahayaan Supermarket The Gourmet Sumber : Dokumen Pribadi 


\section{E. Penghawaan Ruang}

Dari hasil observasi, Supermarket sudah mempunyai penghawaan yang cukup. Bagian indoor menggunakan air conditioner, yang berasal dari AC central Berikut adalah gambar ruangan dengan penghawaannya yang memadai. Penghawaan pada supermarket The Gourmet ,rata-rata suhu saat siang di dalam ruangan adalah sekitar 21oC. Sedangkan saat malam adalah sekitar 20oC. Sedangkan standar penghawaan yang direkomendasikan adalah sekitar 20,5oC-31,0oC. Dengan demikian, sehingga dapat disimpulkan penghawaan ruang supermarket The Gourmet, yang merupakan Supermarket ruang interior ritel, bahwa penghawaan pada cukup memenuhi syarat kenyamanan ruang, dikarenakan data penghawaan memenuhi syarat kenyamanan ruang karena masuk dalam lingkup standar penghawaan yang telah ditetapkan.

\section{F. Sirkulasi dan Aksesibilitas Ruang}

Dari hasil observasi, Supermarket The Gourmet mempunyai pola sirkulasi Linier dan radial. Pola ini mendukung layout kafe yang memanjang. Untuk sirkulasinya terasa cukup untuk minimal satu orang, walaupun ada sedikit yang kurang lebar juga pada beberapa kasus sirkulasi pada display. Tetapi untuk sirkulasi orang jalan, sudah cukup memadai. Untuk sirkulasi radial pada island display cukup memadai jarak untuk beberapa orang. Berikut adalah gambar sirkulasi kafe.' Sirkulasi pada Supermarket The Gourmet, dari 5 kasus sirkulasi yang telah dianalisa datanya, terdapat 4 kasus yang memenuhi standar minimal untuk zona sirkulasi minimal $45.7 \mathrm{~cm}$. Dengan demikian, dapat disimpulkan bahwa Supermarket The Gourmet cukup memenuhi syarat kenyamanan ruang, dikarenakan data sirkulasi ruang memenuhi syarat kenyamanan ruang karena masuk dalam lingkup standar sirkulasi yang telah ditetapkan.

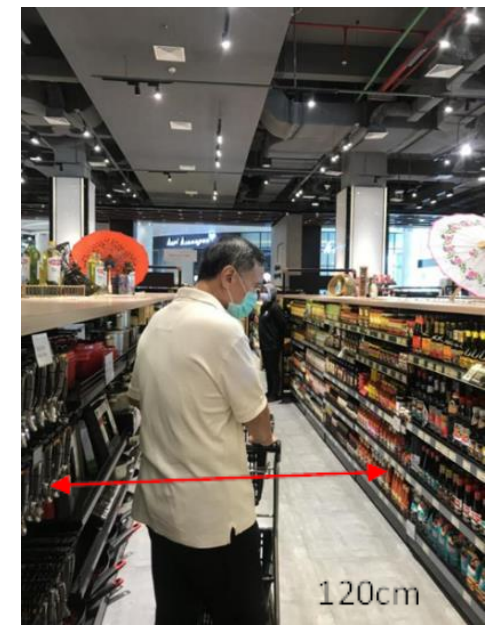

Gambar 8. Area Shelving hanya bisa dilewati 1 trolly Sumber : Dokumen Pribadi

\section{G. Signage dan Graphic}

Dari hasil observasi, Supermarket The Gourmet mempunyai tanda wayfinding untuk produk cukup jelas. Ada dua macam wayfinding di supermarket ini yaitu yang di dinding dan pada fixture display produk. Ukuran font yang cukup, dengan penggunaan font yang jelas dan padat. Penggunaan warna yang bisa jelas dilihat. Tipografi dan warna pada tanda konsisten diseluruh toko. Ada dua macam wayfinding di supermarket ini yaitu yang di dinding dan pada fixture display produk. displaying merchandise di supermarket The gourmet ini, sudah cukup menarik dari tema, desain dan warna. Exterior sampai pada interior supermarket, Desain dan warna pada fixture, shelves dan signage yang konsisten dengan gaya dan tema pada supermarket The Gourmet. 


\section{Simpulan}

Berdasarkan hasil pengamatan dan analisis dari penelitian mengenai "Analisis Kenyamanan Desain Interior Pada Supermarket Ranch Market Di Surabaya" yang dilakukan, maka dapat disimpulkan dari hasil penelitian ini sebagai berikut: Ranch Market dan The Gourmet keduanya mempunyai standar tingkat kenyamanan yang cukup memadai. Dengan demikian dapat dikatakan bahwa Supermarket Ranch Market dan The Gourmet memiliki ruang cukup nyaman sehingga membuat pengunjung merasa nyaman untuk menghabiskan waktu yang lama didalamnya.

Ranch Market meskipun pencahayaannya sudah cukup memenuhi standar pencahayaan ruang ritel, namun penggunaan tone warna lampu masih kurang konsisten, dibagian island display menggunakan warm tone lighting dan pada shelving display menggunakan cool tone lighting sehingga masih terasa agak redup di bagian shelving display, ruang terasa dull dari segi desain interior. Sirkulasi di bagian island display masih ada beberapa kurang cukup memadai dari jarak standard ruang ritel.

The Gourmet memiliki sirkulasi yang masih kurang di beberapa shelving display, sehingga tidak nyaman untuk dilewati dua pengunjung. Signage dari The Gourmet meskipun sudah cukup memadai dari warna, font dan tipografi, tetapi karena signage berada di fixture display, sehingga kurang maksimal untuk pengunjung mencari suatu produk dari jarak jauh.

\section{Daftar Pustaka}

Aulia Rahma. Analisis Faktor-faktor yang Mempengaruhi Keputusan pembelian Pada Supermarket Bilka Di Surabaya. Artikel ilmiah. Surabaya. 2017

Creswell, John W. Design Research. California: SAGE publications. 2009

Hasanah, H. (2017). Teknik-teknik Observasi (Sebuah Alternatif Metode Pengumpulan Data Kualitatif Ilmu-Ilmu Sosial). At-Taqaddum

Kliment, Stephen A. Building Type Basic for Retail and Mixed-used Facilities. John Wiley \& Sons. 2004

Kristanto, V. H. (2018). Metodologi Penelitian Pedoman Penulisan Karya Tulis Ilmiah (KTI). Yogyakarta: CV Budi Utama

Raymundus Giovanni Andre Gunawan. Pengaruh General Exterior, General Interior, Store Layout dan Interior Display Pada Minat beli Konsumen. Skripsi. Yogyakarta. 2018

Restya Hariyanti1, R. Sugeng Basuki. Pengaruh Exterior, General Interior, Store Layout, dan Interior Point of Interest Display Terhadap Keputusan Pembelian di Depot Uceng 'anda' Blitar. J A B Jurnal Aplikasi Bisnis.

Semiawan, C. R. (2010). Metode Penelitian Kualitatif Jenis, Karakteristik dan Keunggulannya. Jakarta: Grasindo.

Yusuf, A. M. (2014). Kuantitatif, Kualitatif, \& Penelitian Gabungan. Jakarta: Kencana. 
Lintas Ruang: Jurnal Pengetahuan \& Perancangan Desain Interior | Vol 8 No 2 Th. 2020 | Hal.27-37 